Magdalena Popiel

\title{
The Aesthetics of Caprice: In the Circle of Visualization
}

DO1:10.18318/td.2015.en.2.13

W hat is it to you?" Borrowing a line from the narrator of Jacques the Fatalist, the scholar of the caprice could respond, "What is it to you?" Such a riposte would be born not of the anti-essentialist stance of the scholar, but more of the frustration elicited by the subject itself. Caprice capable of speech would likely say the same thing as one of Marivaux's allegorical characters:

I am the Je ne sais quoi that pleases in architecture, in furnishings, in gardens, in everything that can be the object of taste. Do not search for me under a certain form; I have a thousand, and not one which is fixed; that's why one sees me without knowing me, without being able to seize me or define me. I am felt; one cannot lay one's hands on me. ${ }^{1}$

Observing the undefined and intangible in other areas than furnishings and gardens is the forte of both "liquid" postmodernity and "solid" modernity. At the dawn of modern art history, as well as the beginning of cultural

1 Pierre de Marivaux, Le Cabinet du philosophe, quoted in Francis X.J. Coleman, The Aesthetic Thought of the French Enlightenment (Pittsburgh: University of Pittsburgh Press, 1971), 86.
Magdalena Popiel

is a professor at the Department of Anthropology of Literature and Cultural Studies in the Faculty of Polish Studies at the Jagiellonian University. She is engaged in the study of the aesthetics of modernism, the theory and history of the novel and Italian literary criticism. Author of the following books: Historia imetafora (1989),

Oblicza wzniostości

Estetykapowieśch mtodopolskiej (1999), Wyspiański. Mitologio nowoczesnego artysty (2007, 2009); author of chapters published in Volume 1 and 2 of Kulturowa teoria literatury. A member of the editorial board of "Przestrzenie Teorii". Chairwoman of the International Association of Polish Studies. Contact mpopiel@interia.pl 
studies, lies the oeuvre of Aby Warburg, and within its boundaries, his fascination with the figure of the "unbeen," or the Nymph. ${ }^{2}$ Georges Didi-Huberman's book Ninfa modern ${ }^{3}$ opens with the ascertainment of the intriguing analogy between these interests of Warburg's and the passion with which Sigmund Freud wrote about Gradiva. ${ }^{4}$ More than just a collection of essays paying homage to the master, the book is also an application of methodology inspired by cultural anthropology. The Florentine Renaissance, with its grand finale in the Classicist-themed paintings of Botticelli, gave Warburg a field in which to explore the "animated life" (bewegtes Leben), and the "animated accessories" (bewegtes Beiwerk) of the figures of antiquity whom he recognized in the art of the Quattrocento. The windswept hair and flowing robes along with the fluid and lively movements of the body formed an instrumentarium of "forms evoking pathos" (Pathosformeln). Huberman continues this story: a beautiful, free goddess, suspended between fluidity and solidity, between rock and air, light as the wind, a Nymph, Gradiva, is subject to degradation in the modern era, like Benjamin's aura; she falls figuratively and literally. Huberman attempts to show the images of the female body and dress as it changes "like the frames of a film" throughout art and literature up to the Parisian tramps and the tattered clothes dumped on the street, immortalized in photographs of the 20 th urban landscape; these iconographic motifs intertwine with mental images. ${ }^{5}$ Memory, desire and time assemble into a configuration of concepts into which this imaginarium is inscribed. ${ }^{6}$

The studies conducted by Warburg, and later Panofsky with his concept of pseudomorphosis, which dealt with interpenetration of the Classical motifs of antiquity with new meanings derived from the Christian cultural sphere, and finally Didi-Huberman's writings on the image of the Nymph all assume a particular non-linear continuity between cultural phenomena. This continuity is possible across chronological and geographical boundaries, despite radical or even paradoxical changes in the "visual parameters" and aesthetic quality (for example, the stripping of pathos or the removal of form). Huberman emphasizes that we must open our eyes in order to see all that passes,

2 Among others, Aby Warburg, "La Nascita di Venere" "e "La Primavera" di Sandro Botticelli (1893), Nimfa fiorentina (1900), Warburg Institute Archive, London III, 118, 1 .

3 Freud's study of Wilhelm Jensen's novel Gradiva was published in 1907.

4 Georges Didi-Huberman, Ninfa Moderna. Essaisur le drapé tombé (Paris: Gallimard, 2002).

5 Most of the images analyzed by Didi-Huberman are photographs of streets strewn with scraps of food and clothes; their authors include Nadar, Thibault, Marville, Atget, L. MoholyNagy's Paris and Berlin series, G. Krull, A. Fleischer, D. Colomb and S. McQueen. 
and we must close our eyes to see all the relationships, correspondences and shifts. In this sense, the anthropology of art/images becomes poetic knowledge.

At some point this rendition of the story of the Nymph encounters the story of caprice; the watershed moment is the birth of modernity.

The Nymph in the Classical tradition could take the form of a Charis (Grace). In the aesthetic of the Renaissance, for example in the treatise Libro della belta e grazia (1590) by Benedetto Varchi, it is grace that begins to function as a category characterized by the famed non so che, different from the kind of beauty that is the domain of reason and norms. ${ }^{7} 16$ th century courtliness and its carefree demeanor combined with sprezzatura, or "studied carelessness" introduce the caprice into the modern aestheticization of everyday life.

\section{A Few Reminders}

"Caprice:" this word has retained the sonority of its Romance origin. According to Italian dictionaries of art, one might regard caprice as an aesthetic concept that is distinguished by its strong anthropological connotations. ${ }^{\mathbf{8}}$ Its large semantic capacity combined with the diversity of visualizations associated with the word make caprice an attractive neighbor for melancholy and grandeur, among others.

The exceptional breadth of meaning found in the word "caprice" can be illustrated by three examples of its diametrically different semantic values:

- in the slightly archaic discourse of love, caprice can appear in the passive or active aspect: to be capricious or to be the victim of someone else's capriciousness; 9

- caprice can be light or dark: sometimes it is cheerful, sophisticated and light, but it can also be paired with negative context, tinged with darkness, suffering and death; it is the space that divides Alfred de Musset's Un Caprice and de Laclos' Les Liaisons dangereuses;

- there is also the caprice in its weak and strong forms, that is the caprice of a child, a woman or an ill person, or the caprice of Fate or God. "A capricious God," however, is an anthropomorphically marked term.

7 Władysław Tatarkiewicz, History of Aesthetics, vol. 3, trans. Chester A. Kisiel (The Hague: Mouton, 1974).

8 Among others, Dizionario enciclopedico dell'arte, ed. Flavio Caroli (Milan: Mondadori 2008); Dizionario di estetica, ed. Gianni Carchia, et al (Rome, Bari: GLF Editori, 2005); Enciclopedia dell'ArteZanichelli (Bologna: Zanichelli, 2004). 
Is the caprice of God thus an anthropomorphization of the concept of Fate in teleological philosophy, or contrarily, is the caprice of a person the consequence of the human experience of the caprices of Fate, the fickleness and randomness of the outside world that becomes interiorized by the human?

In the artistic terminology used in the Polish tradition, caprice most commonly refers to a musical genre: a capriccio is a fantasia build on an imitative structure, a kind of scherzo, a masterly étude (the international master being Paganini, and Grażyna Bacewicz in Poland). In Italian and French culture, capriccio takes the foreground as a genre of painting as well as an extravagant or frivolous architectural form (such as the villa in Comillas designed by Antonio Gaudí).

\section{Figurative Depictions of Caprice}

Caprice, like grace, was part of the visual domain. Władysław Tatarkiewicz referred to Lord Kames, or Henry Home, who argued that "grace is accessible only to the eye."10 An allegorical visualization of Caprice can be found in Cesare Ripa's Iconologia, which is both a summary of the earlier allegorical tradition and a model for the next two centuries. Caprice is presented alongside many other representations of feelings: Fear, Anger, Wonder. The emblematic representation of caprice clearly emphasizes such qualities as weirdness, variability and fantasy. The allegorical figure of caprice is a boy in colorful garb, wearing a hat adorned with feathers. Ripa thus explains the meaning of this garment: "His youth shows his inconstancy; his habit his fickleness. His cap shows that such variety of unaccountable actions are principally in the Fancy." "The transfer of these qualities onto our knowledge of man leads to the following characterization: "A capricious person is he who follows ideas that differ from those commonly found among people, who indulge in different actions, only to jump from one to the other, even if they are of the same type."12 Along with the concepts of caprice in the allegorical tradition, there are also images of caprice created in the 16 th century that emphasize the imagination and craftsmanship of the artist. ${ }^{13}$

10 Władysław Tatarkiewicz, A History of Six Ideas: An Essay in Aesthetics, trans. Christopher Kasparek (The Hague: Njihoff, 1980), 170. Cesare Ripa, Iconologia (Rome: Appresso Lepido Facij, 1593), 48 
Caprice becomes an inalienable component of the Renaissance mannerism, one of the most intriguing fruits of which was the work of Arcimboldo and later Arcimboldian art. Allegorical portraits such as The Librarian, The Lawyer and Rudolf II as Vertumnus rely on a simple game of analogies based on the shapes and symbolism of objects, as well as the masterful craftsmanship of the artist. Reversible paintings such as L'Ortolano (The Vegetable Gardener) belong to an emerging art trend of employing optical illusions. ${ }^{14}$ The permeation of material objects, plants, animals and human forms creates a capricious world of variable images and meanings. This phenomenon is also apparent in the anthropomorphic landscape that emerges in the latter half of the 16th century, leading to the development of the trompe-l'ail. Bizarre anthropomorphic forms found in nature then become the subject of visual creativity. It is no wonder that this form of fantasy caught the interest of 2 oth century surrealists (André Breton and Salvador Dalí); it emphasizes weirdness and peculiarity, wonderfulness tinged with wonder, menacing grotesque and magic - magic that comes from esoteric knowledge, as in the art of Arcimboldo, or the magic of the mystery of the subconscious discovered by Freud.

The connection between Mannerism and Surrealism was pointed out not only by the French founders of the avant-garde movement, but also by art historians and literary scholars. Jan Mukařovský observed that a similar montage technique was used by Arcimboldo and by Nezval in The Absolute Gravedigger. ${ }^{15}$ In the treatise Über Greco und den Manierismus, Max Dvořák reveals premises analogous to the downfall of culture in Mannerism and in the 2oth century interwar period. Recalling this interpretative correspondences, Josef Vojvodik links these body-incrustations or body/headlandscapes to the eradication of the boundary between the microcosm and the macrocosm, and nature and man in the paintings of Salvador Dalí, Max Ernst and René Magritte. ${ }^{\mathbf{1 6}}$

brids or monsters of the sort that can be found in the studies of grotesque figures by Bosch and Giambattista Della Porta's Humana Physiognomia (1586); they are, in a number of ways, an illustration of the 16 th century human imagination's tendency to project metamorphoses.

14 See Roland Barthes, Arcimboldo ou rhetotiqueur et magicien, in Oeuvres completes, vol. 3 , ed. Éric Marty (Paris: Seuil, 1995), 493-511.

15 Jan Mukar̂́ovský, "Sémantický rozbor básnického díla: Nezvalüv Absolutní hrobar̆" in Kapitoly $z$ České poetiky, vol. 2 (Prague: Svoboda, 1948). The author omits, however ${ }_{r}$ the key link in this tradition, namely the 18 th century images of various professions that depicted the composition of tools corresponding to particular trades.

16 JosefVojvodík, "Świat strachu i strach przed światem w czeskim surrealizmie lat trzydziestych iczterdziestych," Teksty Drugie 6 (2007). 


\section{Caprices and Vedute. Toward the Emancipation of Art}

The term "caprice" first appeared in the writing of Vasari and, as is often the case with words that go down in the history of culture, its original meaning was negative, similar to "grotesque" (from raccpriccio: shock, terror). Vasari uses the word to describe ancient and modern artists who violate the rules of mimicking nature. The Counter-Reformation, during which artists who made capricious works of art were accused of ignorance and lies, entrenched the negative meaning of the word.

Capriciousness in painting, or, put briefly, a fantastic landscape, was born out of the veduta. ${ }^{17}$ The veduta, or a picture of place painted in nature, was enormously popular in the visual arts in the unique circumstances that arose during Europe's cultural opening and were tied to the increased mobility of its inhabitants. Creating a new custom known as the Grand Tour, the English, Scandinavians, Germans and the French set off on voyages to the South. It was for these educated travelers that the first guides and collections of vedute were written and painted. This genre of painting was thus born out of a specific social need, and its informative function - which stemmed from the requirement that the artist remain faithful to nature appears dominant.

The peculiar aesthetic tension between vedute and caprices, or between the realism of depiction and attempts to disrupt it, perfectly illustrates certain paths followed by art. When looking at a painting, it is often difficult to discern whether it is a veduta or a fantastic landscape, particularly if it lacks any easily recognizable architectural forms. Sometimes it is only the title containing the term "caprice" that conveys to the viewer the fact that the artist has dispensed with the rules of simply mimicking nature. It is a sign of the stance of the artist, who wishes to exercise his right to free imagination on that specific canvas. An interesting 1766 painting by Belotto titled Architectural Capriccio with a Self-Portrait shows that the genre of the caprice was a type of manifesto of artistic freedom. The piece is a rather extraordinary combination of a self-portrait with a capriccio. In the background, on one of the walls of an odd building, the painter has placed part of a poem by Horace that praises the freedom of the artist. ${ }^{18}$

17 Early forms of capriccio are visible in the work of Baroque artists such as Salvatore Rosa, Giovanni Paolo Pannini and Marco Ricci, as well as Stefano della Bella, who is mentioned in Jacques Callot's Microcosmo della pittura (1657).

18 Note that the fantastic space is completed by the usurping gesture of the artist, who depicts himself dressed in the fine garments of a Venetian nobleman. It is not only the space that has been shaped by the painter, but also the main character of the piece. 
In the 18th century, artists became "depositaries and sometimes prophets of the freedom disgraced on the battlefields." 19 The importance of art that strives to escape the rigid confines of classical discipline increases significantly. No longer understood in terms of the language of power, it achieves a status equated with the increasingly independent language of the artist.

The departure from the faithful image of space occurred in various ways in the 18 th century. Urban landscapes were of particular interest. The picture could depict a fantastic synthesis of actual urban architectural elements, or representations of real buildings combined with invented fragments. The former type of capriccio was a kind of museum collection that encompassed within the painting a set of characteristic architectural forms found mainly in Rome, Padua and Venice. ${ }^{20}$ The space of capricious works is a chessboard in which the movement of realistically treated forms is the basic gesture of a player creating a new reality. The paintings conjured up by the artist remain within the boundaries of probability in the contemporary urban landscape. ${ }^{21}$

Capricious paintings use the framework of the landscape convention as an empty form that can often be filled with various elements using a technique similar to that of the collage. In the 18th century, the main current of this style of painting was headed in two directions. One emphasized the decorative value of art, using it as an ornamental motif in interiors and on furniture. An entire school of furniture-making emerges that specializes in imagined land scape-themed intarsia. ${ }^{22}$ Other artists aimed to fill the space of the landscape with new semantics associated with the key motif of the ruin. Between the sentimental painterliness of the mainly Italian ruins and the freneticism discovered in them by German Romanticism, there is room for the aesthetic of

19 Jean Starobinski, Wynalezienie wolności 1700-1789, trans. Maryna Ochab (Gdańsk: słowo/obraz terytoria, 2006), 15 .

20 More common are capricci that combine realistic and fantastic elements; in a painting by Canaletto, for example, the background of the panorama of a fictitious city includes the Vicenza cathedral and the towers of Padua, while Francesco Guardi introduced Roman architecture into the background of a nondescript city. The artist's imagination would change the location of certain spatial elements, as in Canaletto's Capriccio (1743), in which the famous quadriga of St. Mark's Basilica is transfered to individual pedestals standing in front of the Doge's Palace.

21 See Roland Kanz, Die Kunst des Capriccio. Kreativer Eigensinn in Renaissance und Barok (Munich: Deutscher Kunstverlag, 2002); Colin Eisler "La Tempesta di Giorgione. Il primo " capriccio" della pittura veneziana," Arte Veneta 59 (2002): 85-97 
caprice in the work of such painters as Alessandro Magnasco, Luca Carlevaris, Canaletto, Antonio and Francesco Guardi.

Ruins with elements typical of ancient and renaissance buildings, such as colonnades, terraces, galleries, porticoes and arcades are downright emblematic departures from the harmony and symmetry of classical beauty. The hegemony of order was to be replaced by an indistinct dynamic of lines forming the outline of an irregular shape. The rocks of a ruin gradually give way to vegetation, thus intensifying the sensation of ragged form. In The Analysis of Beauty, William Hogarth praises the line, capable of "lead[ing] the eye [into] a kind of chase." At times the peculiar landscape resembles the effect of an arabesque. The accumulation of architectural elements and plants within the space of the painting does not eliminate the semantic level; on the contrary, it often falls into grandiloquence. The most important sentence uttered in this capricious narrative pertains to the special marriage of culture and nature, permeating each other in constant metamorphosis. In its fully conscious artificiality, caprice is close to the theater; connections between this style of painting and set design were remarked upon by contemporary aesthetes. The capriccio is a form that affects the viewer with the oddity of its juxtapositions, sometimes its disproportions, and the ambiguity of its shapes and meanings.

The genre, which owes much to the extravagance of Mannerism, finds its extension in the works of Giovanni Battista Piranesi. In Carceri d'Invenzione, the architectural caprice achieves the level of a masterpiece and mystery. Georges Poulet devoted an extensive study to the influence of Piranesi's caprices on the imagination of French Romantic poets. ${ }^{23}$ From De Quincey with his Confessions of an English Opium-Eater, through Baudelaire, Alfred de Musset, Victor Hugo and Théophile Gautier, to Mallarmé as well as Kubin and Kafka after him, literature is full of visions of endless staircases and scaffoldings, a spiderweb of ruins and machines. Piranesi is likely the first painter to apply the form of capriccio to the exploration of the human psyche so evocatively and powerfully. The extension of this artistic current sees the appearance of one more work of art: Goya's Caprichos. The date of their publication, 1799 , can be considered symbolic. The concept of the caprice is separated from the traditions associated with vedute, putting at the center of the meaning the artist's clear right to unbridled imagination; a fully individualized system of emotions combines with a moral sensibility and a sense of responsibility for the fate of the community. Caprice remains a gesture of emancipation for the artist, yet it is tinged with fear, suffering,

23 Georges Poulet, "Piranèse et les poètes romantiques français," La Nouvelle Revue Française 160 $(1966), 660-671$. 
evil and death, not unlike the entire 18th century, which ends with cries of freed $m$ and the clank of the guillotine. ${ }^{24}$

\section{The Caprice of the Eye}

The history of caprice as it developed in the genre of painting depicts the entire diversity and fickleness of meanings ascribed to the term. A weirdly meandering aesthetic awareness compelled artists over several centuries to use the word to bind together paintings that reached into different parts of the imagination. Not only was the choice of figurative and landscape forms captured in the process of metamorphosis, fluid transition from one reality to another, interpreted by the notion of caprice, but so was the very process by which paintings were perceived and created.

In his concept of the image, Hans Belting assumes a special primariness of pictures in the lives of people: "We live with pictures and we understand the world through pictures." 25 Pictures that are indivisibly dual: the external and internal image remains both a product of our perception and the fruit of personal or collection symbolization.

This way of thinking about people through what Huberman calls an "epidemic of images" can be found in the work of Gaston Bachelard. His absolutization of the image applied to more than just the poetic imagination that evokes the four elements. Earlier, in 1933, Bachelard published a study titled

24 In the late 18 th century, in $1793_{\text {, }}$ Friedrich Schiller published the essay "On Grace and Dignity, which examined the relationship between these two categories in a manner characteristic of the anthropological aesthetic of Romanticism. Schiller writes that "Grace, therefore, can only characterize willful movements, but also, among these, only those which express moral sentiments. (...) The beautiful soul has no other merit, than that it is. With suchease, as if mere instinct were acting out of it, it carries out the most painful duties of humanity, and the most heroic sacrifice which it exacts from natural impulse comes to view like a voluntary effect of just this impulse. Hence, the beautiful soul knows nothing of the beauty of its cleeds" ("On Grace and Dignity," trans. George Gregory, in Friedrich Schiller: Poet of Freedom (Washington DC: Schiller Institute, 1992), 340, 368). Schiller analyzes the meaning of the belt of grace - an attribute of Venus which she, in her benevolence, can grant to other goddesses or mortals (recall the multiple meanings of the word "grace"). According to his interpretation, grace has five qualities: 1 . it is a changeable beauty; 2 . it is a fortuitous beauty; 3 . it is the beauty of movement; 4 . it operates magically; 5 . it is compared to objects that are less beautiful or even those that are not beautiful. One cannot help but observe that Schiller's grace has much in common with Baudelaire's modern beauty. It appears in both instances as an opposing member to permanent, absolute beauty, which Schiller refers to as "architectonic beauty." In an interesting coincidence, in both cases the image of women's clothing serves as a point of departure for the imagination.

Hans Belting, An Anthropology of Images, (Princeton: Princeton University Press, 2011). 
The World as Caprice and Miniature. ${ }^{26}$ This "philosopher of the moment and the unending," as Błoński described him, ${ }^{27}$ could only find his way, in the end, to the realm of caprice. "The psyche is hungry for images, and the world is the appetite of man," said the author of The Poetics of Reverie. Reverie cannot be described without reference to the mechanism of desire; the image is a "mediation between ourselves and our wanting." ${ }^{28}$ The instrument that is the miniaturization of the world takes part in the creation of this image.

The fact that our sight is the interpretation of reality through the frame of a window has been known since the discovery of linear perspective in the Renaissance. This type of perspective, which Panofsky describes as a symbolic form, ${ }^{29}$ constructs a space that is ordered and homogeneous. The reality that is subject to the rational rules of geometrization is a product of the "immobile eye."

Bachelard, in describing his world as a caprice, refers back to a diametrically opposite tradition. The capricious gaze that shapes a flickering, moving, changing image stems from two sources: the direct rooting of visualization in the matter of the body and the sphere of desire. Caprice is a primary form of the subject's intuition in its traumatic, miraculous and magical dimensions; it is the will to visualize objects in a way that miraculously suspends their inertia: "it is the commanding power that entertains itself by rotating the kaleidoscope of distant miniatures [...] Long before humans incarnated Homo faber, it was Puerlusor who possessed the world with his toy." ${ }^{30}$

The notion of caprice in Bachelard's concept has a variety of anthropological implications. The author contrasts caprice with the force of action, a voluntary activity that evaluates it in an ambiguous, ambivalent way. $\mathrm{He}$ emphasizes that it is the youthful energy of caprice, and not the power of activity, that shapes the self-awareness in its plurality and freedom. The fantasy of caprice allows us a chance to abandon the distant and indifferent world. The distance that forms in the immobile structure of the "view through the window" is eliminated, and we can once again experience individual objects and find ourselves inside the cosmos.

26 Gaston Bachelard "Le Monde comme caprice et miniature," Recherches Philosophiques 3(19331934), quoted in Bachelard, "Il mondo come capriccio e miniature," ed. Flavia Conte (Milano: Claudio Gallone, 1997)

27 Jan Błoński Introduction to Gaston Bachelard, Wyobraźnia poetycka. Wybór pism, ed. Henryk Chudak, trans. Henryk Chudak and Anna Tatarkiewicz (Warszawa: PIW, 1975), 15. Bachelard, Wyobraźnia poetycka.

29 Erwin Panofsky, "Die Perspektive als 'symbolische Form'," Vortrage der Bibliotek Warburg, vol. 4. (1924-1925), 258-330. 


\section{The World as Caprice - Georg Simmel's Aesthetic of Lightness}

Traditional depictions of caprice are strongly linked to the image of a place that is sometimes regarded at once as the caprice of nature and civilization: Venice. In his description of Venice and the surrounding islands in Iconologia, Cesare Ripa used the term capriccilagunari. The ragged, irregular line that meanderingly and uncertainly marks the boundary between sea and land made the association with the caprice of nature unavoidable. This bizarre quirk of nature posed a challenge to the imagination, which, at the time, was preoccupied with solidifying images of the radical separation between land and water in the landscape of our planet.

In later narratives about Venice, caprice becomes a Cassirerian way of symbolically perceiving the city, an aspect of descriptions striving to uncover its mystery. Georg Simmel also searches for his own truth about Venice. ${ }^{31}$ To him the city has the ambiguous beauty of adventure and rootlessness; a one-dimensional superficiality, a fickle and at once seemingly illusory variability at the defining features of capricious Venice. The unnoticeable overlapping of the seasons, "the green of its few gardens rooted somewhere in stone or in the air, or perhaps rootless, is not subject to change," "the city belongs neither to the land or the water;" its numerous bridges neither divide nor connect anything, and the "narrow Venetian streets slither over the countless bridges as if they were flat roads." All of this makes Venice an

"artificial city" where everyone moves as if on stage; preoccupied with vain dreams or endeavors that lead to nothing, they incessantly emerge from behind cormers, only to immediately disappear around the next one, and they always have in them something of an actor who is nothing off stage, as it is only on stage that the game is played, with no cause in the reality of the previous moment and no effect in the reality of the next moment. ${ }^{32}$

Simmel's capriccio, describing an almost fantastic Venetian landscape, contains a crucial conclusion. Venice

has become a symbol of exceptional order about the forms of our understanding of the world: here is a surface that has abandoned the soil,

31 Georg Simmel, "Wenecja," in Simmel, Most i drzwi. Wybór esejów, trans. Małgorzata Łukasiewicz (Warszawa: Oficyna Naukowa, 2006) 
a pretense in which there is no being, and yet it presents itself as something complete and substantial, as the contents of a life actually being lived. 33

Simmel does not like Venice, but he is captivated by Florence, because "art is perfect, far from any artificiality only when it becomes something more than art" - such is Florence. And yet it is Venice that becomes the discovery of a new way of understanding the world. A surface that does not refer to any depth, but creates instead the autonomous and real content of life. Capricious Venice, Simmel's capriccio veneziano becomes a prefiguration of the aesthetic of lightness and of the fluid postmodern world.

According to Georges Didi-Huberman, we must open our eyes to feel caprice. It is then that we will see how caprice builds the fantastic landscape of nature and architecture, how it assumes human forms, how it draws the map of the world. But we must then close our eyes so that it may give rise to what Milan Kundera called "a capricious cluster," at once light and unbearable.

Translation: Arthur Barys

33 Ibid., 182 